\title{
EFFECTS OF IRRIGATION LEVELS ON THE YIELD OF CHICKPEA (CICER ARIETINUM LINN) DUE TO INCIDENCE OF HELICOVERPA ARMIGERA
}

\author{
Keshav Mehra* and Veer Singh \\ Department of Entomology, College of Agriculture, Swami Keshwanand Rajasthan \\ Agricultural University, Bikaner-334 001(Rajasthan)
}

Keywords: Gram pod borer, Chickpea, Irrigation, Pod damage, Seed yield

\begin{abstract}
Effects of four different irrigation levels viz., One irrigation at 50 per cent flowering stage, one irrigation at grain filling/pod initiation stage, two irrigations (one at 50 per cent flowering + one at grain filling stage), control (without irrigation) on the incidence of gram pod borer, Helicoverpa armigera (Hubner) on chickpea were studied during Rabi, 2014-15 and 2015-16 at Research Farm, College of Agriculture, Bikaner (Rajasthan), India. Results revealed that the highest mean larval population (3.12 larvae per 5 plants) and maximum pod damage $(33.24 \%)$ were recorded in the crop which was irrigated twice viz., one at 50 per cent flowering stage and second at grain filling stage. The lowest larval population (2.03 larvae per 5 plants) with minimum pod damage $(8.34 \%)$ was recorded in the crop where irrigation was not given. The maximum seed yield $(11.05 \mathrm{q} / \mathrm{ha})$ was obtained from the crop which was irrigated two times and minimum seed yield (7.56 $\mathrm{q} / \mathrm{ha}$ ) was obtained in control.
\end{abstract}

Chickpea, Cicer arietinum Linn also known as a Bengal gram or Gram is an important pulse crop, grown under irrigated and non-irrigated conditions. Chickpea is nutritionally very rich source of protein (18-22\%), carbohydrate (61-63\%) and fat (4-5\%) and also contains calcium, phosphorus, iron, niacin, vitamin B and C (Ahlawat and Omprakash 1996). In India, the yield potential of gram is quite low due to the poor management of crop and serious damage done by the pests. The gram pod borer (Helicoverpa armigera Hubner, Lepidoptera: Noctuidae) is the most serious pest of important agricultural crops like tomato, cotton, chickpea, pigeonpea and also for cereals, oil seeds and vegetable crops etc. However it mainly attacks chickpea (Jat and Ameta 2013). This pest causes heavy economic losses in the gram. The larval stage of this pest causes economic damage and a single larva alone can destroy 30 to 40 pods before the maturity (Reed and Pawar 1982). It is reported to cause yield losses mainly due to pod damage which range from 14 to 38 per cent, whereas if the environmental conditions are favorable to pod borer, then pod damage goes up to 90 to 95 per cent (Sachan and Katti 1994, Pandey and Ujagir 2008). Ambulkar et al. (2011) stated that the irrigation levels have a great impact on the incidence of this pest. Hence, keeping the above facts in mind, present study was carried out to know the effects of different irrigation levels on the incidence of $H$. armigera in chickpea.

The experiment was conducted at Research Farm, College of Agriculture, Bikaner (Rajasthan), India for two consecutive years in the Rabi season during 2014-15 and 2015-16. To study the effect of different irrigation levels chickpea variety GNG-1581 were sown in a plot of $2.4 \mathrm{x} 3 \mathrm{~m}^{2}$. There were four different irrigation levels, (i) one irrigation at 50 per cent flowering stage (ii) one irrigation at grain filling/ pod initiation stage (iii) two irrigation one at 50 per cent flowering and the second at grain filling stage and (iv) control (without irrigation after sowing). The experiment was laid out in randomized block design and row to row and plant to plant distance of 30 and $10 \mathrm{~cm}$, respectively was maintained. These different irrigation levels constitute four treatments and each treatment was replicated five times.

*Author for correspondence: <keshav.mehra35@gmail.com>. 


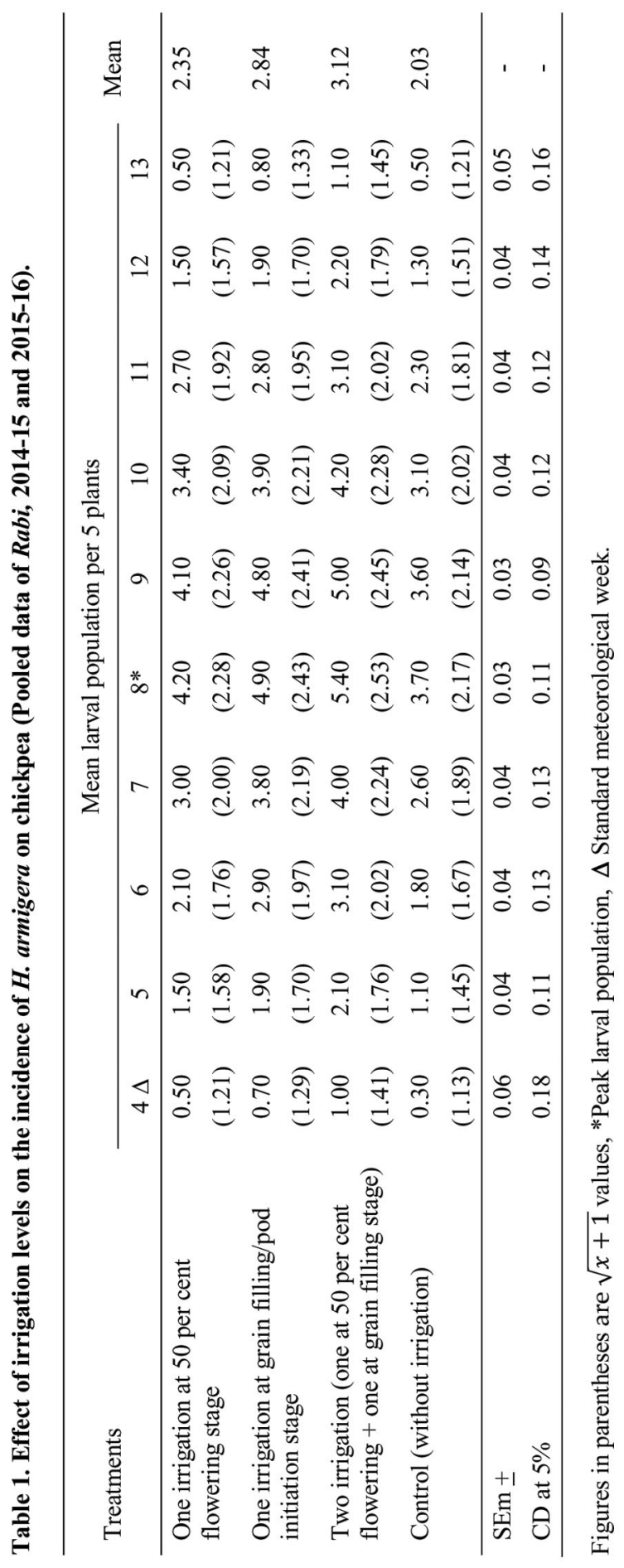




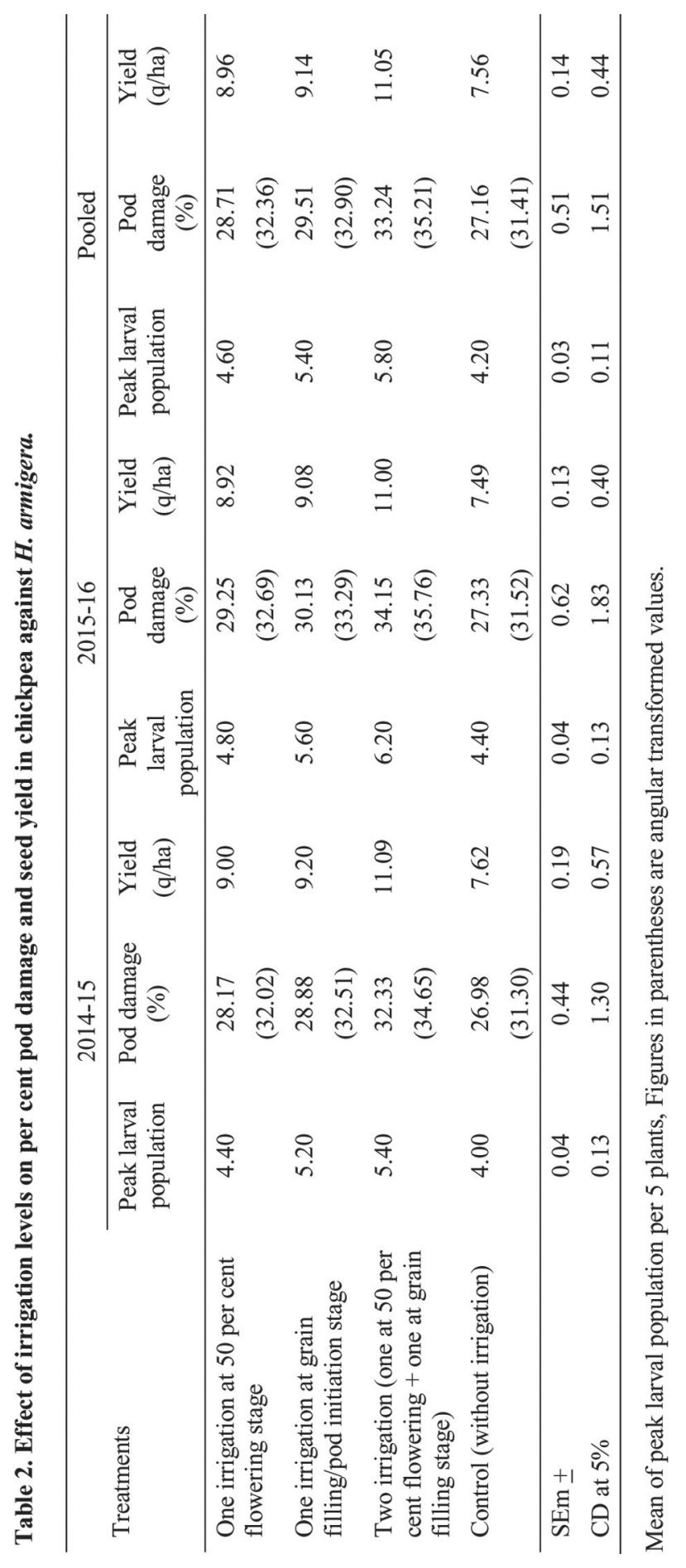


The weekly observations on the incidence of $H$. armigera infesting gram were recorded on five randomly selected tagged plants in each plot by counting the number of healthy and damaged pods. Grain yield was also recorded at the time of threshing. The data obtained on gram pod borer population from the experimental field were transformed into $\sqrt{x+1}$ values and were subjected to analysis of variance. The per cent pod damage was also calculated by using the following formula.

$$
\text { Pod damage }(\%)=\frac{\text { No. of infested pods }}{\text { Total number of pods }} \times 100
$$

The pooled data of both the years presented in the Table 1 revealed that peak population of $H$. armigera ranged from 3.70 to 5.40 larvae per five plants in different irrigation levels. The minimum larval population (3.70 larvae per 5 plants) was observed at no irrigation level which was at par with one irrigation applied at 50 per cent flowering stage (4.20 larvae per five plants). The maximum larval population was observed with two irrigation levels (5.40 larvae per 5 plants) which was at par with one irrigation applied at grain filling/pod initiation stage (4.90 larvae per 5 plants). The mean larval population ranged from 2.03 to 3.12 larvae per five plants. Meena (1999) also recorded highest population of $H$. armigera on chickpea crop which was irrigated twice $v i z$. , at pre and post flowering stage whereas the lowest population in the crop where irrigation was not given. Ambulkar et al. (2011) also recorded maximum larval population under the treatment when one irrigation was applied at branching stage followed by two irrigation levels one applied at branching stage and other at podding stage and minimum being when irrigation was not applied.

The pooled data on pod damage and seed yield (Table 2) indicated that minimum pod damage (27.16\%) was observed with no irrigation which was at par with one irrigation applied at 50 per cent flowering stage (28.71\%) and one irrigation applied at grain filling/ pod initiation stage $(29.51 \%)$, whereas, maximum pod damage $(33.24 \%)$ was recorded in two irrigation levels. The highest seed yield $(11.05 \mathrm{q} / \mathrm{ha})$ was obtained from the crop which was irrigated two times whereas minimum seed yield $(7.56 \mathrm{q} / \mathrm{ha}$ ) was obtained from the crop which was not irrigated. The yield 9.14 and $8.96 \mathrm{q} / \mathrm{ha}$ was obtained when one irrigation applied at grain filling/ pod initiation stage and one irrigation applied at 50 per cent flowering stage, respectively and both were found comparable with each other. These results are also in agreement with the findings of Meena (1999) and Ambulkar et al. (2011) who reported minimum seed yield and minimum pod damage in non irrigated crop while maximum pod damage and maximum seed yield in the chickpea crop which was irrigated twice.

The meager information on the effect of irrigation levels on the incidence of $H$. armigera infesting chickpea was available, however, Rembold and Winter (1982) mentioned that the use of irrigation and fertilizer enhance luxuriant crop growth leading to better foliage coverage in chickpea which provides a suitable micro climate for Helicoverpa moth to lay eggs and better food for the larval development.

\section{Acknowledgements}

Authors are thankful to Department of Science and Technology, New Delhi for providing financial support. The authors are also thankful to the Dean, COA, and Head, Department of Entomology, COA, Bikaner for providing necessary research facilities for conducting the experiment. 


\section{References}

Ahlawat IPS and Omprakash 1996. Nutritional value of chickpea grains. Principles Agronomy \& Crops. pp.43.

Ambulkar PL, Saxena, AK and Dixit H 2011. Effect of date of sowing and irrigation level on the incidence of Helicoverpa armigera (Hubner) on chickpea crop. Int. J. Plant Protec. 4(2): 301-304.

Jat SK and Ameta OP 2013. Relative efficacy of biopesticides and newer insecticides against Helicoverpa armigera (Hub.) in tomato. The Bioscan. 8(2): 579-582.

Meena 1999. Management of gram pod borer, Heliothis armigera infesting gram. M.Sc. Thesis, RCA, Udaipur.

Pandey R and Ujagir R 2008. Effect of intercropping on Helicoverpa armigera infesting chickpea. Ann. Pl. Protec. Sci. 16(2): 320-324.

Reed W and Pawar CS 1982. Heliothis : A Global problem. In Proceedings of International Workshop on Heliothis Management. ICRISAT, Patancheru. pp. 9-41.

Rembold H and Winter E 1982. The chemists role in host plant resistance studies. Proceeding of the international workshop on Heliothis management, Patancheru, Nov. 15-20, 1981, ICRISAT, pp.241-250.

Sachan JN and Katti G 1994. Integrated Pest Management. Proceeding of International Symposium on Pulses Research, April 2-6, IARI 2-6, IARI, New Delhi, India. p. 23-30.

(Manuscript received on 16 May, 2021; revised on 7 November, 2021) 